\title{
On the time stability of the output-capital ratio
}

\author{
C. D'Adda and A. E. Scorcu \\ University of Bologna
}

\begin{abstract}
This paper is concerned with the role of the output-capital ratio in growth models. In the first part we highlight the behaviour of the output-capital ratio along the balanced growth path in the models of Solow (1956) and Romer (1986). In the second part we assess the stability of the ratio for some industrial countries.
\end{abstract}

JEL classification: O40, N10

Keywords: growth, output-capital ratio, cointegration, endogenous break

\author{
Carlo D'Adda \\ Department of Economics, University of Bologna \\ Strada Maggiore 45, 40125 Bologna, Italy \\ tel. +390512092618 \\ fax: +390512092664 \\ e-mail:dadda@spbo.unibo.it \\ Antonello E. Scorcu \\ Department of Economics, University of Bologna \\ Strada Maggiore 45, 40125 Bologna, Italy \\ tel. +390512092611 \\ fax: +390512092664 \\ e-mail: scorcu@spbo.unibo.it
}




\section{On the time stability of the output-capital ratio}

\section{Foreword and content}

This paper concerns the long run behaviour of the output-capital ratio. From the theoretical point of view, several growth models suggest the existence of a stable output-capital ratio. In the Harrod-Domar model a fixed output-capital ratio is explicitly assumed. A constant ratio emerges also in the steady state equilibrium of the Solow (1956) that allow for substitution between labour and capital model and, more recently, in the so called $a K$-type models firstly presented by Romer (1986). However, from the empirical point of view, only few papers explicitly address this issue. In particular, this paper analyses the stability of the output-capital ratio drawing on the now available long-run time series of these variables.

The structure of the paper is as follows. Section 2 compares some features of Solow and the $a K$ model. Its purpose is to show that the assumption of a stationary output-capital ratio in the long run is consistent with several theoretical views; sections 3 and 4 address the empirical problem of the time stability of the output-capital ratio in some major industrial economies using cointegration tecniques. The main empirical findings are summarised in the conclusion.

\section{2. $\quad$ The Solow model and the aK model}

The Solow model can be shortly recalled by means of few equations (undefined symbols have the usual meaning). Be the production function:

$$
\mathrm{Y}=\mathrm{K}(\mathrm{t})^{\alpha}(\mathrm{L}(\mathrm{t}) \mathrm{F}(\mathrm{t}))^{1-\alpha}
$$

where $\mathrm{F}(\mathrm{t})=\mathrm{F}(0) \mathrm{e}^{\gamma \mathrm{t}}$ represents an exogenous labour augmenting technical progress and $\mathrm{L}(\mathrm{t})=$ $\mathrm{L}(0) \mathrm{e}^{\mathrm{nt}}$ represents labour as a function of time, $\gamma$ and $\mathrm{n}$ being exogenous parameters.

In steady growth:

$$
[\mathrm{dY}(\mathrm{t}) / \mathrm{dt}] / \mathrm{Y}(\mathrm{t})=[\mathrm{dK}(\mathrm{t}) / \mathrm{dt}] / \mathrm{K}(\mathrm{t})
$$

Equations [1] and [2] imply:

$$
[\mathrm{dY}(\mathrm{t}) / \mathrm{dt}] / \mathrm{Y}(\mathrm{t})=\mathrm{n}+\gamma
$$

If capital does not depreciate, (capital) accumulation in steady growth is:

$$
[\mathrm{dK}(\mathrm{t}) / \mathrm{dt}] / \mathrm{K}(\mathrm{t})=\mathrm{s} \mathrm{Y}(\mathrm{t}) / \mathrm{K}(\mathrm{t})
$$

From [2], [3] and [4] the endogenous steady state output-capital ratio is obtained ${ }^{1}$ :

$$
\mathrm{Y}(\mathrm{t}) / \mathrm{K}(\mathrm{t})=\mathrm{a}=[\mathrm{n}+\gamma] / \mathrm{s}
$$

Using [2], [4] and [5] the steady growth rate can be expressed in terms of the product between the output-capital ratio and the saving rate:

$$
[\mathrm{dY}(\mathrm{t}) / \mathrm{dt}] / \mathrm{Y}(\mathrm{t})=\mathrm{a} \mathrm{s}
$$

So we can also say that along the steady state path the growth rate of the economy is given by the saving rate (a parameter that ultimately reflects intertemporal preferences and possibly policy decisions) times the endogenous output-capital ratio, but from equation [3], that causally comes

\footnotetext{
${ }^{1}$ The same result is obtained in the exogenous growth model augmented with human capital, as in Mankiw, Romer and Weil (1993).
} 
before equation [6], we see that the exogenous technical progress, not the saving behaviour, is the growth factor. True that in the short run (i.e. out from the steady state path), if equation [5] is temporarily violated the output-capital ratio takes time to adjust, and the saving rate affect the growth rate for a while. But any attempt at increasing the saving (and investment) rate would be shortly frustrated by a correspondent reduction of $a$.

In the $a K$ model the production function is:

$$
Y(t)=a H(t) K(t)^{\alpha} L(t)^{1-\alpha}
$$

where $a$ is an exogenous output-capital ratio and $\mathrm{H}$ represents an endogenous technical progress and $\mathrm{L}(\mathrm{t})=\mathrm{L}(0) \mathrm{e}^{\mathrm{nt}}$, $\mathrm{n}$ being an exogenous parameter. The endogenous technical progress is described by:

$$
H(t)=(K(t) / L(t))^{1-\alpha}
$$

From equations [7] and [8] it follows that:

$$
\mathrm{Y}(\mathrm{t})=\mathrm{a} \mathrm{K}(\mathrm{t})
$$

which implies:

$$
(\mathrm{dY}(\mathrm{t}) / \mathrm{dt}) / \mathrm{Y}(\mathrm{t})=(\mathrm{dK}(\mathrm{t}) / \mathrm{dt}) / \mathrm{K}(\mathrm{t})
$$

As investment is again an exogenous (and supposedly constant) fraction of output, from [4], [9] and [10] we obtain:

$$
(\mathrm{dY}(\mathrm{t}) / \mathrm{dt}) / \mathrm{Y}(\mathrm{t})=\mathrm{s} \mathrm{a}
$$

Equation [6] of the Solow model and [11] of the $a K$ model formally coincide. However in the Solow model the exogenous factor is technical progress, whereas in the $a K$ model it is the output-capital ratio.

It is also clear that in the Solow model the balanced growth rate of the economy turns out to depend only upon exogenous variables (as far as we take technical progress as given). Therefore this model may be classified as a model of exogenous growth. On the contrary in the $a K$ model the growth rate of the economy depends upon accumulation behaviour. We have therefore endogenous growth (Jones and Manuelli, 1990). In particular, the economy starts with a low per-capita stock of capital and the output capital ratio decreases as the growth process unfolds, like in the Solow model.

What is the reason why it may be useful analysing growth processes by means of models of steady growth in which the state variables (or most of them) grow at the same rate, whereas "parameters" can be considered roughly constant? The reasonable answer is that variables such as the output-capital ratio and the distributive shares, although changing over the time and showing medium run tendencies, cannot but being stationary in the long run, i.e. trend-less. In similar cases the representation of the observed evolution process by means of steady growth models (or models of regular growth) is the most obvious stylisation.

Both models purport to comply with empirical data describing long run growth (notably a different dynamics of labour and capital, the first being lower than the second in industrialised countries). Long run stability of the output-capital ratio supports both models. The possible instability of the ratio (which reflects the instability of its determinants, see [5] and [9]) might raise doubts on the empirical fruitfulness of the concept of steady growth, upon which relies a large part of the cross section evidence. 
Our interest in the long term growth must be stressed. On empirical grounds, testing for the stability of the output-capital ratio seems to be crucial if the Solow or Romer models are to be taken as the reference "parable" of the growth process ${ }^{2}$.

\section{The experience of seven industrialised countries}

Several empirical analyses try to assess whether the empirical evidence supports the exogenous (Solow) growth hypothesis or the endogenous growth hypothesis, the $a K$ model being one of the most prominent examples of the latter group ${ }^{3}$. These analyses, in fact, suffer from a major weaknesses, as they introduce the balanced growth rate as a maintained (untested) hypothesis. One implication common to the Solow and the $a K$ model is the stationarity of the output-capital ratio on the balanced growth path. This feature has been often neglected in the empirical analysis, possibly because it requires a time series approach whereas the availability of relatively short time series for a large number of countries has shifted the interest towards the crosssection analysis. In this paper we address the problem of the time stability of the output-capital ratio in some industrial economies.

Long term time series of the aggregate output and capital stock are available for the US, Japan, UK and Italy. Shorter series are available for France, Germany and the Netherlands. GDP and capital stock data (except Italy) are from Maddison (1995a and 1995b). The capital stock series comprise buildings, plant and machinery and have been constructed following the same procedure for each country - assuming a rectangular depreciation profile and the same economic life for each type of capital - 39 years for non-residential buildings and 14 years for plant and machinery. As for Italy, output and capital stock data are from Rossi, Sorgato and Toniolo (1993). In this latter case the stock of non-residential capital includes private and public expenditures in plant and machinery. Although the definitions and the assumptions about the capital stock are different in the two studies, the overall concept of capital is similar, and in principle comparable. All the series are in constant 1990 international dollars.

Table 1 - Values of the output-capital ratio and rates of change of per-capita real GDP

\begin{tabular}{|c|c|c|c|c|c|c|c|c|}
\hline & $\begin{array}{l}\text { Sample } \\
\text { period }\end{array}$ & $\begin{array}{c}\text { initial } \\
\mathrm{Y} / \mathrm{K}\end{array}$ & $\begin{array}{l}\text { final } \\
\mathrm{Y} / \mathrm{K}\end{array}$ & $\begin{array}{l}(3) \\
\text { relative } \\
\text { change } \\
\mathrm{Y} / \mathrm{K}\end{array}$ & $\begin{array}{c}(4) \\
\text { relative } \\
\text { change } \\
\text { Y per capita }\end{array}$ & $\begin{array}{c}(5) \\
\text { relative } \\
\text { change } \mathrm{Y} / \mathrm{K} \\
\text { (per year) }\end{array}$ & $\begin{array}{l}\text { (6) } \\
\text { relative change } \\
\text { Y per capita } \\
\text { (per year) }\end{array}$ & $\begin{array}{c}(7) \\
(6) /(5)\end{array}$ \\
\hline$\overline{\text { USA }}$ & 1890-1992 & 0.329 & 0.412 & 0.251 & 5.348 & 0.002 & 0.018 & 8.315 \\
\hline UK & 1870-1992 & 1.109 & 0.551 & -0.503 & 3.823 & -0.006 & 0.013 & -2.271 \\
\hline Italy & $1890-1990$ & 0.640 & 0.519 & -0.189 & 8.192 & -0.002 & 0.022 & -10.711 \\
\hline Japan & 1890-1992 & 1.408 & 0.331 & -0.765 & 18.953 & -0.014 & 0.030 & -2.113 \\
\hline Netherlands & 1950-1992 & 0.486 & 0.438 & -0.098 & 1.888 & -0.002 & 0.026 & -10.418 \\
\hline Germany & $1935-1991$ & 0.416 & 0.431 & 0.035 & 3.643 & 0.001 & 0.028 & 45.196 \\
\hline France & 1950-1991 & 0.613 & 0.452 & -0.264 & 2.401 & -0.007 & 0.030 & -4.072 \\
\hline
\end{tabular}

Source: our elaboration on Maddison (1995a, b) and Rossi et al. (1993)

We have already pointed out that even if the output-capital ratios of the seven envisaged countries are subject to change, this is not enough to dismiss the empirical relevance of the stylised fact. In fact, we are interested not only in evaluating the stability of the ratio per se, but also relatively to other key variables in the growth process.

\footnotetext{
${ }^{2}$ The stationarity of the ratio has been recently challenged. Romer (1989), "the constancy of the capital-output ratio can still be judged to be a useful target for theories of growth, but so also might the apparent departures from this tendency for low-income countries", p. 62, and Maddison (1995b), "the new estimates [of the capital stock] falsify the notion that capital-output ratios have been stable over time" p. 135-6, are two remarkable examples of this view.

${ }^{3}$ Among others, Makiw, Romer and Weil (1993) and Bernanke and Gürkaynak (2001).
} 
In Table 1 we compare the initial output-capital ratio of each country with its final value. A fall emerges for most of the countries: $19 \%$ in Italy, $9 \%$ in the Netherlands, $75 \%$ in Japan. In Germany the ratio remained roughly constant, while in the US there is a $25 \%$ increase.

Are these findings consistent with the mentioned stylised fact? The answer requires to examine the output change as well. For example, in the period 1890-1992 per capita GDP increased by 19 times in Japan, 8 times in Italy (column 4). The comparison between the annual rates of change, which neutralises for the different length of the series gives a striking result: for the US, Italy and Netherlands the change in $\mathrm{Y} / \mathrm{K}$ is approximately ten times lower than in per capita $\mathrm{Y}$ and for Germany much more (columns 5 and 6). Having in mind these figures, a certain degree of time stability must be recognised to the output-capital ratio.

It is also to be remarked that country differences exhibit a tendency to reduce over the time. Table 2 presents (cross country) coefficients of variation for the output-capital ratio and the percapita GDP computed at the beginning and at the end of the sample period. In the 1890-1992 sample (panel a) the geographic dispersion of the capital intensity diminishes over time: the final value of the coefficient of variation of the output-capital ratio is half of its initial value. Similar conclusions apply to the post WWII 7-countries sample (panel b).

\section{Insert Figures 1-6}

Table 2 - Coefficients of variation among countries

\begin{tabular}{|c|c|c|c|c|c|c|}
\hline \multicolumn{7}{|c|}{ Coefficient of variation } \\
\hline \multicolumn{4}{|c|}{ a) USA, UK, Italy*, Japan } & \multicolumn{3}{|c|}{$\begin{array}{l}\text { b) USA, UK, Italy*, Japan, France**, } \\
\text { Germany**, Netherlands }\end{array}$} \\
\hline & 1890 & 1950 & 1992 & & 1950 & 1992 \\
\hline $\mathrm{Y} / \mathrm{K}$ & 0.555 & 0.522 & 0.223 & $\mathrm{Y} / \mathrm{K}$ & 0.430 & 0.161 \\
\hline $\mathrm{K}$ per-capita & 0.968 & 0.960 & 0.349 & $\mathrm{~K}$ per capita & 0.698 & 0.257 \\
\hline Y per-capita & 0.560 & 0.618 & 0.148 & Y per capita & 0.460 & 0.113 \\
\hline
\end{tabular}

Source: our elaboration on Maddison (1995a, b) and Rossi et al. (1993)

* 1990 for Italy, ** 1991 for France and Germany

The well known result of convergence in per-capita GDP levels among the industrialised countries emerges neatly: the (relative) dispersion in per-capita GDP in the current Nineties is $1 / 4$ of that of the Fifties. Note that, because of the stability of the output-capital ratio, there is a tendency to convergence also in the per-capita stock of capital, whose variability falls by $2 / 3$ in the same period. However, this process begins only in the aftermath of WWII. In the long run the convergence might be the exception rather than the rule: the growth patterns of a given group of countries change within a given period of time (as suggested by several cross countries studies) and also over time. Unsurprisingly, the empirical results based on relatively short time series (like the Summer-Heston data set) turn out to be fragile. Figures 1-6 show graphically these findings.

In this set-up the convergence which characterises the "golden age of growth" of the current Fifties and Sixties is the intended result of growth-enhancing policies set forth by Western countries, possibly requiring several other elements in addition to physical and human capital accumulation (Feinstein, Temin and Toniolo, 1997). In fact, after WWII the technological achievements of the leader quickly spread throughout the other Western countries, whose $\mathrm{Y} / \mathrm{K}$ ratios start to decrease towards the US level. However, the final output-capital ratios of the followers (except Japan) are still higher than the leader country ${ }^{4}$.

\footnotetext{
${ }^{4}$ The lack of convergence in the first period still requires an explanation. It may be the case that the free trade in factors and output that characterised the Gold Standard era may have allowed some countries to reach their long run structure the countries in our sample were not far from their respective steady state (St. Aubyn, 1999, Cellini and Scorcu, 2000). Taylor (1999) finds instead evidence of convergence among a group of seven selected countries during the period 18701914. He emphasises (factor and productivity) country convergence via factor reallocation, rather than accumulation, as in the $a K$ framework.
} 
The catching-up begins in different periods according to countries. In particular, until the Thirties in Italy and in the UK the output-capital ratio remains nearly constant, consistently with the balanced growth view ${ }^{5}$, while the convergence of the ratio towards the US level starts only after WWII and, for Italy, possibly vanishes in the last decade. Japan started with a low capital endowment with respect to the leader. As it appears from Figure 6, in this case the catching-up in capital intensity seems to take place in an almost continuous way, in spite of war disruptions ${ }^{6}$. During the Seventies the output-capital ratio rises even more than in the past, up to reach and pass the US level.

In the period under scrutiny the US has represented the technological frontier of the industrialised countries and has occupied a special position in terms of GDP, capital stock and technical progress. In the period $1890-1930$ the $\mathrm{Y} / \mathrm{K}$ ratio is nearly constant. During the Great Depression capacity utilisation falls and the ratio reaches an historical minimum. In the war years capital utilisation and Y/K quickly become very high, reaching a maximum in 1944. After 1950 the positive trend disappears and the time path of the output-capital ratio is again smooth, with an average level higher than in the first half of the sample.

This once and for all movement, in our opinion, does not imply a dramatic weakening of the hypothesis of stability of the $\mathrm{Y} / \mathrm{K}$ ratio, which remains roughly constant in the two (long) periods 1890-1940 and 1940-1990.

\section{Econometric analysis}

In analysing the stationarity of the country output-capital series (in logs), we look for the cointegration relationship ${ }^{7}$ :

$$
\log \left(\mathrm{Y}_{\mathrm{t}}\right)=\mathrm{a}+\mathrm{b} \log \left(\mathrm{K}_{\mathrm{t}}\right)+\mathrm{u}_{\mathrm{t}} \quad \mathrm{u} \sim\left(0, \sigma^{2}\right)
$$

and test for $b=1$.

Table 3 shows the results based on MLE procedures. In most of the cases the trace and eigenvalue tests suggest the emergence of a long run relation. The estimated $b$ coefficient is often not far from 1, even if the formal tests reject this restriction. More precisely, $b$ is below 1 for all the countries except the US.

Consider the consequences of the omission of a once and for all change in the output-capital ratio for the estimation of $b$. An increase in $\mathrm{Y} / \mathrm{K}$ leads to an upward bias with respect to the predicted long run value $b=1$ whereas a downward bias is expected in the case of a drop in $\mathrm{Y} / \mathrm{K}$, as a consequence of the convergence process toward the leader.

Therefore, the results of Table 3 - the lack of cointegration (for the UK over the period 1870-1992, and for the Netherlands over the period 1950-92) or the emergence of cointegration between output and capital with an estimated value for $b$ lower than 1 for the followers and $b$ higher than 1 for the US - may be explained by the existence of a break in the co-integration relationship.

Allowing for a regime shift in the long run relationship could make the overall picture clearer. In fact Figures 1-6 suggest a different result for the leader country and the followers. In the former case the slope of the relationship remains roughly constant over the century under scrutiny: a drop in the slope is expected for the followers, because of the recent catching up process towards the US.

The use of the Gregory e Hansen (1996) endogenous break selection procedure enables us to analyse the existence of a break in the co-integration relation ${ }^{8}$.

\footnotetext{
${ }^{5}$ For the UK the output-capital ratio series begins in 1870 (Maddison, 1995b).

${ }^{6}$ Also in the case of Italy WWII capital disruptions cause a temporary increase of the output-capital ratio. As it appears from the data, the value attained by the ratio at the end of the Thirties is reached again only at the end of the Sixties.

${ }^{7}$ Lau and Sin (1997) contrasted the Solow and Romer models and derived their empirical predictions in terms of cointegration relationships between output and capital, reaching results similar to ours.

${ }^{8}$ In order to assess the robustness of the results, after identifying the breakpoint we have also estimated this cointegration relationship with an error correction model both using non-linear OLS and the Johansen MLE procedure.
} 
Consider a possible regime shift in the static regression equation [12] concerning the intercept and the slope coefficient occurring at time $\tau$ with $\tau \in\{1, \ldots, T\}$ and consider a dummy variable $\mathrm{D}_{\mathrm{t}}{ }^{\tau}$, such that:

$$
\mathrm{D}_{\mathrm{t}}^{\tau}=\left\{\begin{array}{l}
0 \text { if } \mathrm{t}<\tau \\
1 \text { if } \mathrm{t}>\tau
\end{array}\right.
$$

Let us consider the co-integration relationship

$$
\log \left(\mathrm{Y}_{\mathrm{t}}\right)=\mathrm{a}_{1}+\mathrm{a}_{2} \mathrm{D}_{\mathrm{t}}^{\tau}+\mathrm{b}_{1} \log \left(\mathrm{K}_{\mathrm{t}}\right)+\mathrm{b}_{2} \log \left(\mathrm{K}_{\mathrm{t}}\right) \mathrm{D}_{\mathrm{t}}^{\tau}+\mathrm{u}_{\mathrm{t}}^{\tau}
$$

If the series $\left\{\mathrm{u}_{\mathrm{t}}^{\tau}\right\}$ is stationary, we can say that $\log \left(\mathrm{Y}_{\mathrm{t}}\right)$ and $\log \left(\mathrm{K}_{\mathrm{t}}\right)$ cointegrate in the presence of a regime shift, involving the intercept and the slope. The cointegrating vector has changed at time $\tau$, with $\mathrm{a}_{1}$ and $\mathrm{b}_{1}$ measuring the shifts in the coefficients since $\tau$.

\begin{tabular}{|c|c|c|c|c|c|}
\hline & $\begin{array}{l}\text { Sample } \\
\text { Period }\end{array}$ & $\begin{array}{l}\text { Number of } \\
\text { co-integrating } \\
\text { relationship }\end{array}$ & $\begin{array}{l}\text { VAR } \\
\text { Length }\end{array}$ & $\begin{array}{l}\text { Estimated } \\
b \text { coefficient }\end{array}$ & $\begin{array}{l}\text { Test } \chi^{2}(1): \\
b=1\end{array}$ \\
\hline \multirow[t]{2}{*}{ USA } & $1892-1992$ & 1 & 2 & 1.186 & $\begin{array}{l}4.384 \\
{[0.036]}\end{array}$ \\
\hline & $1950-1992$ & 1 & 2 & 0.972 & $\begin{array}{l}1.432 \\
{[0.231]}\end{array}$ \\
\hline \multirow[t]{2}{*}{ UK } & $1872-1950$ & 1 & 2 & 1.011 & $\begin{array}{l}0.036 \\
{[0.849]}\end{array}$ \\
\hline & 1950-1992 & 1 & 2 & 0.567 & $\begin{array}{l}10.102 \\
{[0.001]}\end{array}$ \\
\hline Italy & 1892-1990 & 1 & 4 & 0.892 & $\begin{array}{l}9.316 \\
{[0.002]}\end{array}$ \\
\hline Japan & 1892-1992 & 1 & 2 & 0.701 & $\begin{array}{l}12.443 \\
{[0.000]}\end{array}$ \\
\hline France & 1950-1992 & 1 & 2 & 0.805 & $\begin{array}{l}5.388 \\
{[0.020]}\end{array}$ \\
\hline Germany & 1935-1992 & 1 & 2 & 0.791 & $\begin{array}{l}24.553 \\
{[0.000]}\end{array}$ \\
\hline
\end{tabular}

Table 3: Co-integration between GDP and capital stock.

Gregory and Hansen (1996) work out a procedure for the endogenous determination of $\tau$, testing for the stationarity of the residuals of the cointegration relationship [13]. The procedure is as follows: (i) for each $\tau$ in the reasonable range $0.15 \mathrm{~T}<\tau<0.85 \mathrm{~T}$ run regression [13]; (ii) compute the corresponding $\operatorname{ADF}(\tau)$ statistics ${ }^{9}$ based on $\left\{u^{\tau} t\right\}$; (iii) choose the value of $\tau$ which is consistent with $\mathrm{ADF}_{\mathrm{t}} *=\inf _{\tau} \mathrm{ADF}(\tau)$ and compare $\mathrm{ADF}_{\mathrm{t}} *$ with the relevant critical value.

The result of this procedure is shown in Table 4.

In column 3 it is shown, for each country, the year in which a significant regime shift emerges in the cointegration relationship, on the basis of the $\mathrm{ADF}_{t} *$ test. The pre- and post-break estimates of the constant term and the slope coefficients are shown in columns 4-5 and 6-7, respectively. We test for the break in the intercept and the slope (columns 8 and 9) and for the restriction $b=1$ in the pre- and post break period (columns 10 and 11).

The overall picture is similar and the results (available upon request from the authors) are not reported for the sake of brevity.

${ }^{9}$ The test has been developed also in terms of the Perron-Phillips $Z_{t}$-statistics. Whereas the statistics $A D F^{*}$ and $Z_{t}{ }^{*}=\inf _{\tau} Z(\tau)$ have the same asymptotic distribution, the latter appears to perform better in small size samples, according to Montecarlo evidence. Only the ADF test is considered in the text. 
For the US the analysis proceeds in two steps. In the first step we estimate the cointegration relationship allowing for changes in both intercept and slope. However since the $\chi(1)^{2}$ test $b_{1}+b_{2}=1$ is below the 5\% significance level (3.099, with a P-value 0.078$)$ in the second step we estimate the long run cointegration relationship with an intercept change only. These latter results are shown in Table 4: the point estimate of the elasticity of output with respect to capital is now equal to 0.96 , not significantly different from 1: apart a change in 1938, the $\mathrm{Y} / \mathrm{K}$ ratio remains constant over a century.

Table 4 - Co-integration relationship between GDP and capital stock with endogenous break

\begin{tabular}{|c|c|c|c|c|c|c|c|c|c|c|}
\hline (1) & $\begin{array}{l}(2) \\
\text { sample } \\
\text { period }\end{array}$ & $\begin{array}{l}\text { (3) } \\
\text { break year } \\
\text { (ADF test) }\end{array}$ & (4) & $a_{1}+a_{2}$ & (6) & $b_{1}+b_{2}$ & $\begin{array}{l}(8) \\
\text { Test } \\
\chi^{2}(1): \\
a_{2}=0\end{array}$ & $\begin{array}{l}(9) \\
\text { Test } \\
\chi^{2}(1): \\
b_{2}=0\end{array}$ & $\begin{array}{l}(10) \\
\text { Test } \\
\chi^{2}(1): \\
b_{1}=1\end{array}$ & $\begin{array}{l}(11) \\
\text { Test } \chi^{2}(1) \text { : } \\
b_{1}+b_{2}=1\end{array}$ \\
\hline USA & $\begin{array}{l}1890- \\
1992\end{array}$ & $\begin{array}{l}1938 \\
(-9.657)\end{array}$ & -0.672 & 0.407 & 0.963 & - & $\begin{array}{l}120.806 \\
{[0.000]}\end{array}$ & $\begin{array}{l}131.847 \\
{[0.000]}\end{array}$ & $\begin{array}{l}2.6458 \\
{[.104]}\end{array}$ & - \\
\hline UK & $\begin{array}{l}1870- \\
1992\end{array}$ & $\begin{array}{l}1948 \\
(-5.962)\end{array}$ & -0.402 & 5.798 & 1.045 & 0.555 & $\begin{array}{l}317.377 \\
{[0.000]}\end{array}$ & $\begin{array}{l}312.920 \\
{[0.000]}\end{array}$ & $\begin{array}{l}4.069 \\
{[0.000]}\end{array}$ & $\begin{array}{l}708.686 \\
{[0.000]}\end{array}$ \\
\hline Italy & $\begin{array}{l}1890- \\
1990\end{array}$ & $\begin{array}{l}1959 \\
(-5.760)\end{array}$ & 0.046 & 3.040 & 0.957 & 0.743 & $\begin{array}{l}30.632 \\
{[0.000]}\end{array}$ & $\begin{array}{l}27.195 \\
{[0.000]}\end{array}$ & $\begin{array}{l}3.189 \\
{[0.074]}\end{array}$ & $\begin{array}{l}60.149 \\
{[0.000]}\end{array}$ \\
\hline Japan & $\begin{array}{l}1890- \\
1992\end{array}$ & $\begin{array}{l}1954 \\
(-8.904)\end{array}$ & 4.152 & 3.676 & 0.634 & 0.702 & $\begin{array}{l}1.793 \\
{[0.181]}\end{array}$ & $\begin{array}{l}6.109 \\
{[0.013]}\end{array}$ & $\begin{array}{l}350.872 \\
{[0.000]}\end{array}$ & $\begin{array}{l}242.838 \\
{[0.000]}\end{array}$ \\
\hline Nether. & $\begin{array}{l}1950- \\
1992\end{array}$ & $\begin{array}{l}1978 \\
(-8.022)\end{array}$ & -0.590 & 2.461 & 0.992 & 0.751 & $\begin{array}{l}12.809 \\
{[0.000]}\end{array}$ & $\begin{array}{l}13.622 \\
{[0.000]}\end{array}$ & $\begin{array}{l}0.299 \\
{[0.584]}\end{array}$ & $\begin{array}{l}15.264 \\
{[0.000]}\end{array}$ \\
\hline France & $\begin{array}{l}1950- \\
1992\end{array}$ & $\begin{array}{l}1966 \\
(-6.957)\end{array}$ & -2.793 & 5.269 & 1.185 & 0.585 & $\begin{array}{l}253.189 \\
{[0.000]}\end{array}$ & $\begin{array}{l}243.564 \\
{[0.000]}\end{array}$ & $\begin{array}{l}26.856 \\
{[0.000]}\end{array}$ & $\begin{array}{l}846.621 \\
{[0.000]}\end{array}$ \\
\hline Germany & $\begin{array}{l}1935- \\
1991\end{array}$ & $\begin{array}{l}1952 \\
(-7.002)\end{array}$ & -19.241 & 3.703 & 2.429 & 0.692 & $\begin{array}{l}43.152 \\
{[0.000]}\end{array}$ & $\begin{array}{l}41.581 \\
{[0.000]}\end{array}$ & $\begin{array}{l}28.340 \\
{[0.000]}\end{array}$ & $\begin{array}{l}172.363 \\
{[0.000]}\end{array}$ \\
\hline
\end{tabular}

Note: in the case under scrutiny the relevant $5 \%$ and $1 \%$ critical values for the $\mathrm{ADF}_{t}{ }^{*}$ statistics for co-integrating relationship with a shift in the slope and in the intercept are -5.50 and -5.97 , respectively.

The followers find themselves in a different position. A graphical inspection of the output capital ratios for the UK and Italy suggests a peculiar pattern: in the first half of the sample the ratio remains roughly constant, whereas countries succeed in reducing their distance from the US in terms of per-capita stock of capital since the current Fifties. This transition process is rather slow and a problem may arise in the empirical analysis: standard cointegration techniques allow for a sudden change of regime in the long run relationship but the adjustment in $\mathrm{K}$ must be described as slow transition process. Neglecting this process is likely to imply a serious mis-specification of the long run equilibrium dynamics ${ }^{10}$. However, it is difficult to disentangle from this transition process the new (possibly stationary) long run level of the output-capital ratio. In this case a regime shift makes it possible to identify the "long" run relationship for a sub-period only. For Japan, on the contrary, the catching up process is apparent during the whole century.

The countries for which only post WWII data are available, exhibit more or less pronounced catching up processes. The emergence of a break (1978 for the Netherlands, 1966 for France and 1952 for Germany) must be evaluated with caution, because of the poor finite sample properties of these ADF type tests. The long run unit elasticity between output and capital is rejected for France and Germany, whereas is not for the Netherlands over the period 1950-77.

The empirical evidence of Table 4 suggests a more careful modelling of the short run effects. Some time series tests have been developed in this perspective. Jones (1995) and Kocherlakota and Yi, (1996 and 1997) proposed some tests within the framework of the $a K$ model. They regress the growth rate against the gross investment ratio I/Y (possibly augmented with other regressors):

$$
\left(\mathrm{Y}_{\mathrm{t}}-\mathrm{Y}_{\mathrm{t}-1}\right) / \mathrm{Y}_{\mathrm{t}-1}=\mathrm{a}\left(\mathrm{I}_{\mathrm{t}} / \mathrm{Y}_{\mathrm{t}}\right)-\delta
$$

\footnotetext{
${ }^{10}$ A downward bias in the estimate of $b$ might emerge; see Caballero (1994).
} 
In the light of our framework this approach has two weaknesses: i) $\mathrm{I}_{\mathrm{f}} / \mathrm{Y}_{\mathrm{t}}=\mathrm{a}_{\mathrm{t}} \Delta \mathrm{K}_{\mathrm{t}} / \mathrm{K}_{\mathrm{t}}+\mathrm{a}_{\mathrm{q}} \delta_{\mathrm{t}}$ might be $\mathrm{I}(1)$ because of a once and for all change in $a$ and/or in $\delta$, as the composition of the overall stock of capital changes over time and different types of capital have different depreciation rates; ii) the long run restriction given by the cointegration relation between $\mathrm{Y}$ and $\mathrm{K}$ is not explicitly taken into account.

We model the stability of the output-capital ratio from a different perspective. Rather than considering successive theoretical restrictions of a general model, we use a specific model to test whether the $\mathrm{Y} / \mathrm{K}$ ratio is stationary. In particular, and differently from equations [12] and [13], a cointegration vector $(1,-1)$ is imposed a priori. Moreover the adjustment in the output-capital ratio which takes place after WWII is modelled by using short run temporary dummies.

$$
\log \left(\mathrm{Y}_{\mathrm{t}} / \mathrm{K}_{\mathrm{t}}\right)=\mathrm{a}_{1}+\mathrm{a}_{2} \mathrm{D}_{\tau}+\Sigma \alpha_{\mathrm{i}} \mathrm{DU} \mathrm{U}_{\mathrm{i}}+\mathrm{u}_{\mathrm{t}}
$$

$\mathrm{DU}_{\mathrm{i}}$ is a temporary 5-year dummy such that $\mathrm{DU}_{\mathrm{i}}=1$ for $\mathrm{i}-4 \leq \mathrm{t} \leq \mathrm{i}$ and $\mathrm{D}_{\mathrm{i}}=0$ otherwise, whereas $\mathrm{D}_{\tau}$ is such that $D_{\tau}=0$ for $t<\tau$ and $D_{\tau}=1$ for $t \geq \tau$. The Gregory and Hansen procedure is used in the identification of the period $\tau$. The short-run adjustment process is described by a VAR with lag length equal to 2 . An ML procedure is used to estimate this relationship and the results are shown in Table 5.

As far as the US is concerned, a unit elasticity between output and capital throughout the sample 1890-1992 is not rejected. The same conclusion holds also for the Netherlands, the UK, over the period 1870-1948, and Italy, if a temporary dummy for the period 1941-45 is included in the regression. On the contrary, the $a K$ model can be rejected for Japan and the UK over the whole period 1870-1992. A stationary output-capital ratio (with a break) emerges for France and Germany only if rather complex dynamic adjustments are allowed for. For Germany, in particular, the inclusion of four 5-year dummy variables is required.

In conclusion, the hypothesis of long run stationary output-capital ratio retains some empirical support.

Table 5- Cointegration between output and capital in the $a k$ model

\begin{tabular}{llllllll}
\hline & Sample period & $\begin{array}{l}\text { Break } \\
\text { year }\end{array}$ & $\begin{array}{l}\text { Max. } \\
\text { eigenval. } \\
\text { Test }\end{array}$ & $\begin{array}{l}\text { Trace } \\
\text { Test }\end{array}$ & $\mathrm{a}_{1}$ & $\mathrm{a}_{2}$ & $\begin{array}{l}\text { Short run } \\
\text { Dummies DU }\end{array}$ \\
\hline USA & $1890-1992$ & 1938 & $27.251^{* *}$ & $29.507^{* *}$ & 0.384 & -1.204 & - \\
UK & $1870-1948$ & - & $8.866^{*}$ & $8.866^{*}$ & 0.135 & - & - \\
& $1870-1992$ & 1948 & 10.011 & 12.148 & - & - & - \\
Italy & $1892-90$ & 1959 & $18.459^{* *}$ & $20.921^{* *}$ & -0.123 & -0.428 & $1941-45$ \\
Japan & $1892-92$ & 1954 & 5.140 & 7.991 & - & - & - \\
Netherlands & $1952-92$ & 1978 & $19.460^{* *}$ & $20.910^{* *}$ & -0.681 & -0.134 & - \\
France & $1952-92$ & 1966 & $18.128^{* *}$ & $24.655^{* *}$ & 3.682 & -6.343 & $1956-60,1961-64$ \\
Germany & $1935-91$ & 1952 & $18.251^{* *}$ & $19.953^{*}$ & -0.725 & -0.068 & $1951-55,1956-60$ \\
& & & & & & & $1961-65,1966-70$ \\
\hline
\end{tabular}

-Notes: $*$ and $* *$ indicates significance at the $10 \%$ and $5 \%$ level, respectively.

\section{Insert figures 7 and 8}

\section{Conclusion}

In the empirical evaluation of the growth processes, a trade off between the length of the series and the number of countries is likely to emerge. In most of the recent analyses the number of countries considered is large but the time period considered (the years after WWII) is quite short the Summer-Heston data-set is a typical example. Even if in these cases the cross section format is the natural one, most of these empirical results are not robust to minor changes in the estimation period and/or in the econometric specification. 
Since long run time series are available for some developed countries, a dynamic analysis of the growth processes is possible (and worthwhile). This paper has developed an exploratory analysis along these lines, testing for the stationarity of the output-capital ratios for seven industrialised countries. The majority of the cases analysed exhibit stationary ratios for extended periods in accordance with the steady state behaviour of both the $a K$ model and the exogenous growth model.

The empirical evidence suggests a useful distinction between the leader country, the US, and the followers, France, Germany, Italy, Japan, the Netherlands and the UK, even if the differences among the structure of the economies, in terms of values of the ratios, show a tendency to reduce progressively over time.

\section{References}

Bernanke, B. S. and Gürkaynak, R. S. (2001) "Is Growth exogenous? Taking Mankiw, Romer, and Weil Seriously", NBER Working Paper no. 8365.

Caballero, R. J. (1994) "Small sample bias and adjustment costs", Review of Economics and Statistics, vol. 76, pp. 52-58.

Cellini R. and A. E. Scorcu (2000) "Segmented stochastic convergence across the G-7 countries", Empirical Economics, vol. 25, pp. 463-474.

Feinstein C. H., P. Temin P. and G. Toniolo (1997) The European economy between the wars, Oxford, Oxford University Press, 1997.

Gregory A. W. and B. E. Hansen (1996) "Residual-based Tests for Cointegration in Models with Regime shifts", Journal of Econometrics, vol. 70, pp. 99-126.

Jones C (1995) "Time series test of endogenous growth models", Quarterly Journal of Economics, vol. 100, pp. 495-525.

Jones L. E. and R. Manuelli, A Convex Model of Equilibrium Growth: Theory and Policy Implications, Journal of Political Economy, vol. 98, pp. 1008-38.

Kocherlakota N. R. and Yi K.-M. (1996) "A Simple Time Series Test of Endogenous vs. Exogenous Growth Models: An Application to the United States", Review of Economics and Statistics, vol. 78, pp. 126-34.

Kocherlakota N. R. and Yi K.-M. (1997) "Is There Endogenous Long-Run Growth? Evidence from the United States and the United Kingdom", Journal of Money, Credit, and Banking, vol. 29, pp. 235-62.

Lau S. P. and Sin C. (1997) "Observational equivalence and a stochastic cointegration test of the neoclassical and Romer's increasing returns models", Economic Modelling, vol. 14, pp. 39-60.

Maddison A. (1995a) Monitoring the World Economy, OECD, Paris.

Maddison A. (1995b) "Standardized Estimates of Fixed Capital Stock: A Six Country Comparison", in Explaining the Economic Performance of Nations, Edward Elgar, Aldershot, pp.137-66. 
Makiw, N. G., Romer, D. and Weil, D. N. (1992) "A Contribution to the Empirics of Economic Growth”, Quarterly Journal of Economics, vol. 107, pp. 407-37.

Romer P. (1986) "Increasing Returns and Long Run Growth", Journal of Politcal Economy, vol. 94, pp. 1002-37.

Romer P. (1989) "Capital Accumulation and Long Run Growth", in R. Barro (ed.), Modern business cycle theory, Oxford, Basil Blackwell, pp. 51-127.

Rossi N., Sorgato A., Toniolo G. (1993) "I conti economici italiani: una ricostruzione statistica, 1890-1990”, Rivista di Storia Economica, vol. X, pp. 1-47.

Solow R (1956) "A contribution to the theory of economic growth", Quarterly Journal of Economics, vol. 70, pp. 65-94.

St. Aubyn M. (1999) "Convergence across industrialized countries (1890-1989): New results using time series methods" Empirical Economics, vol. 24, pp. 23-44.

Taylor A. M. (1999) Sources of convergence in the late nineteeth century, European Economic Review, vol. 43, pp. 1621-1645.

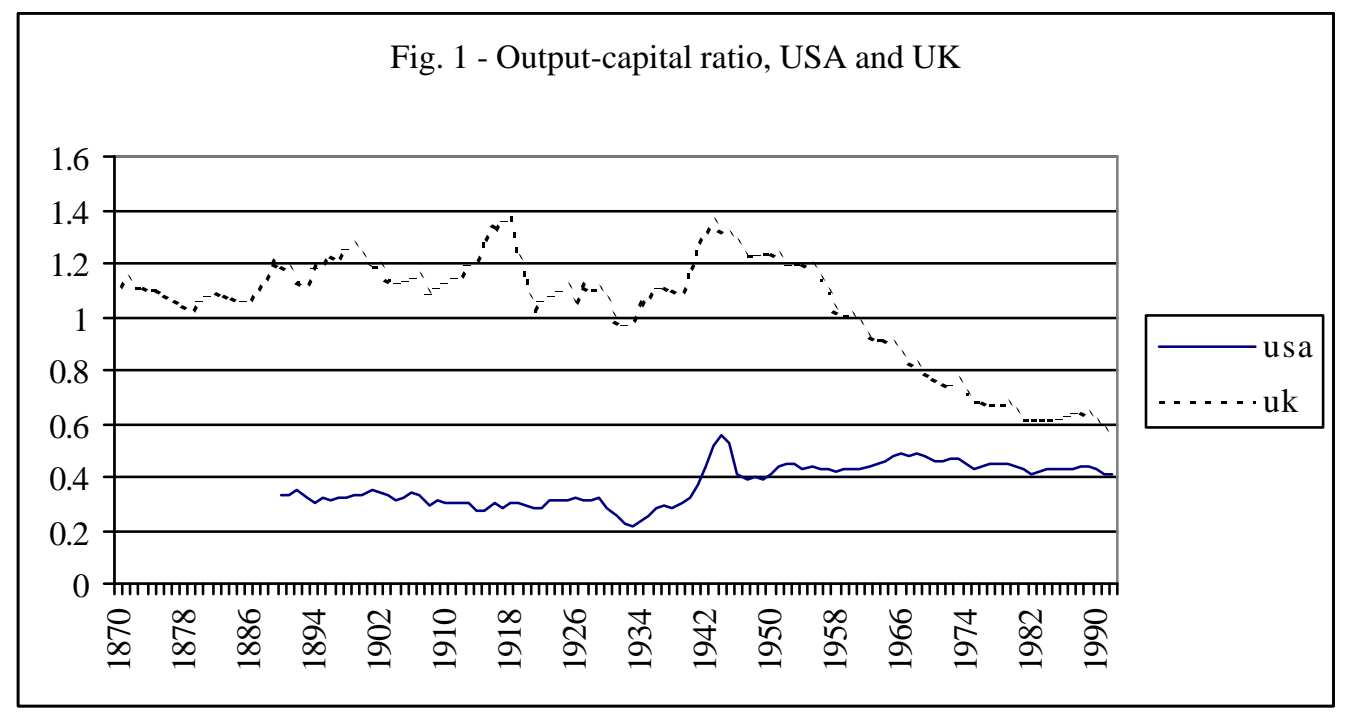



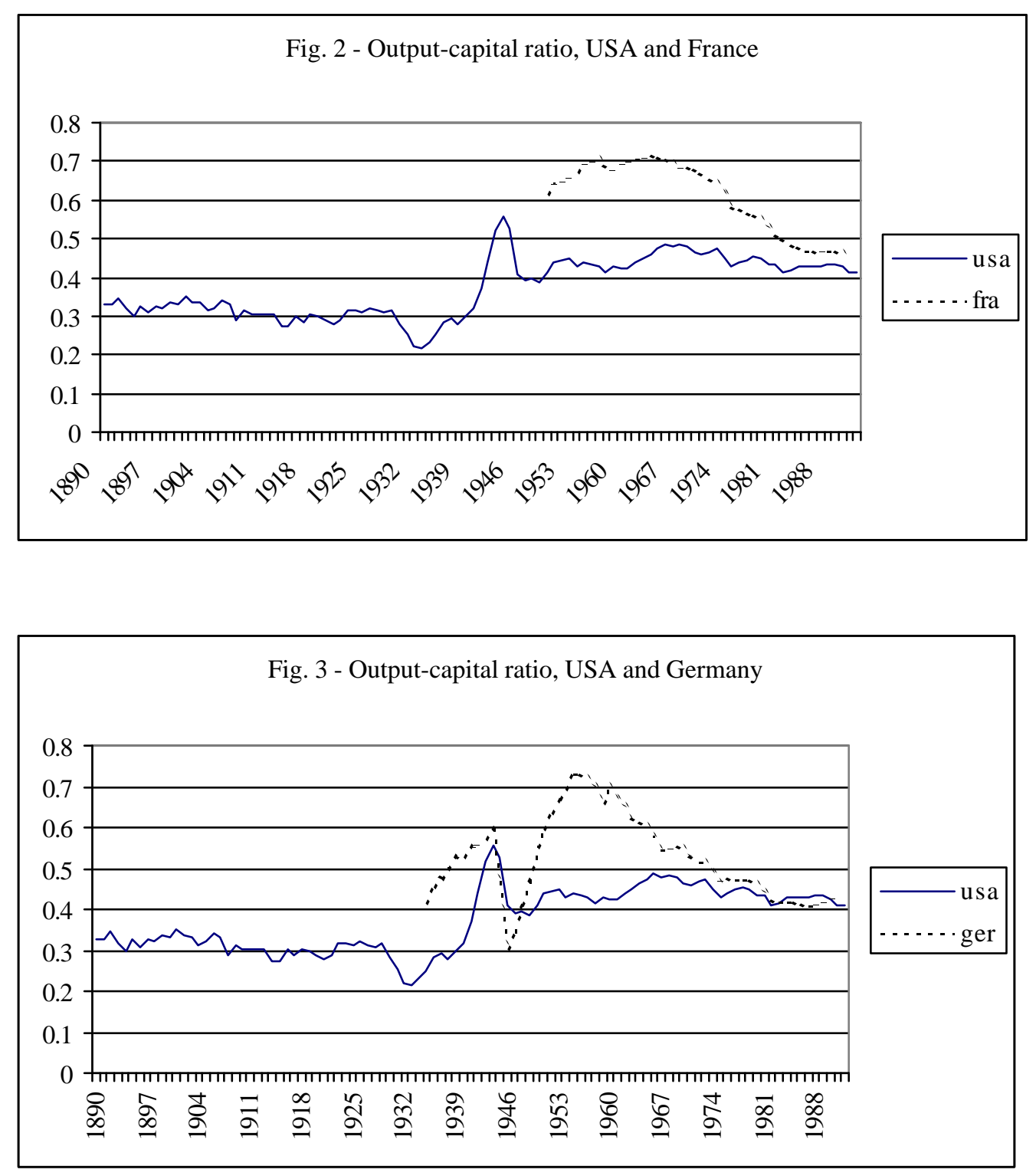

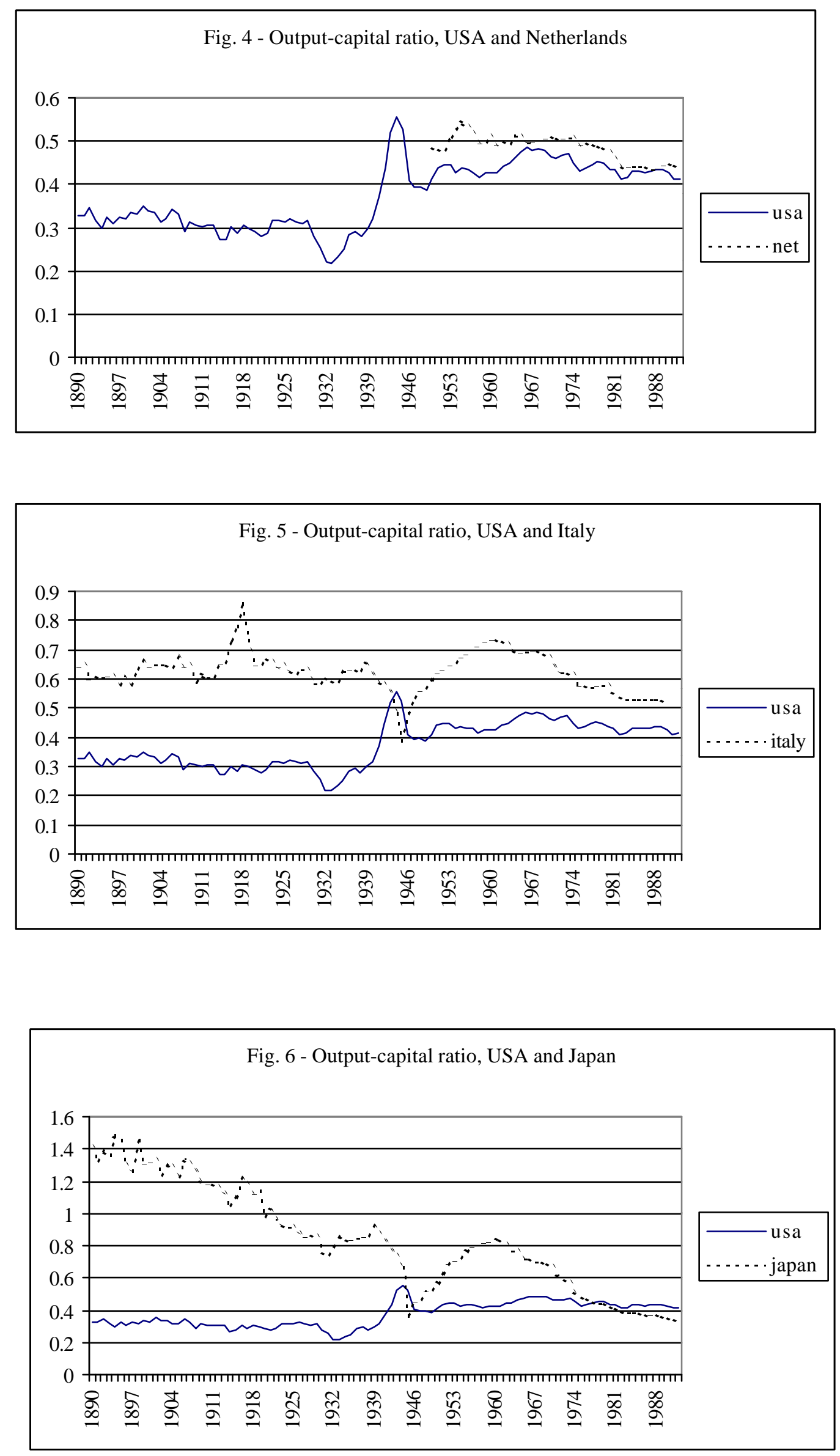

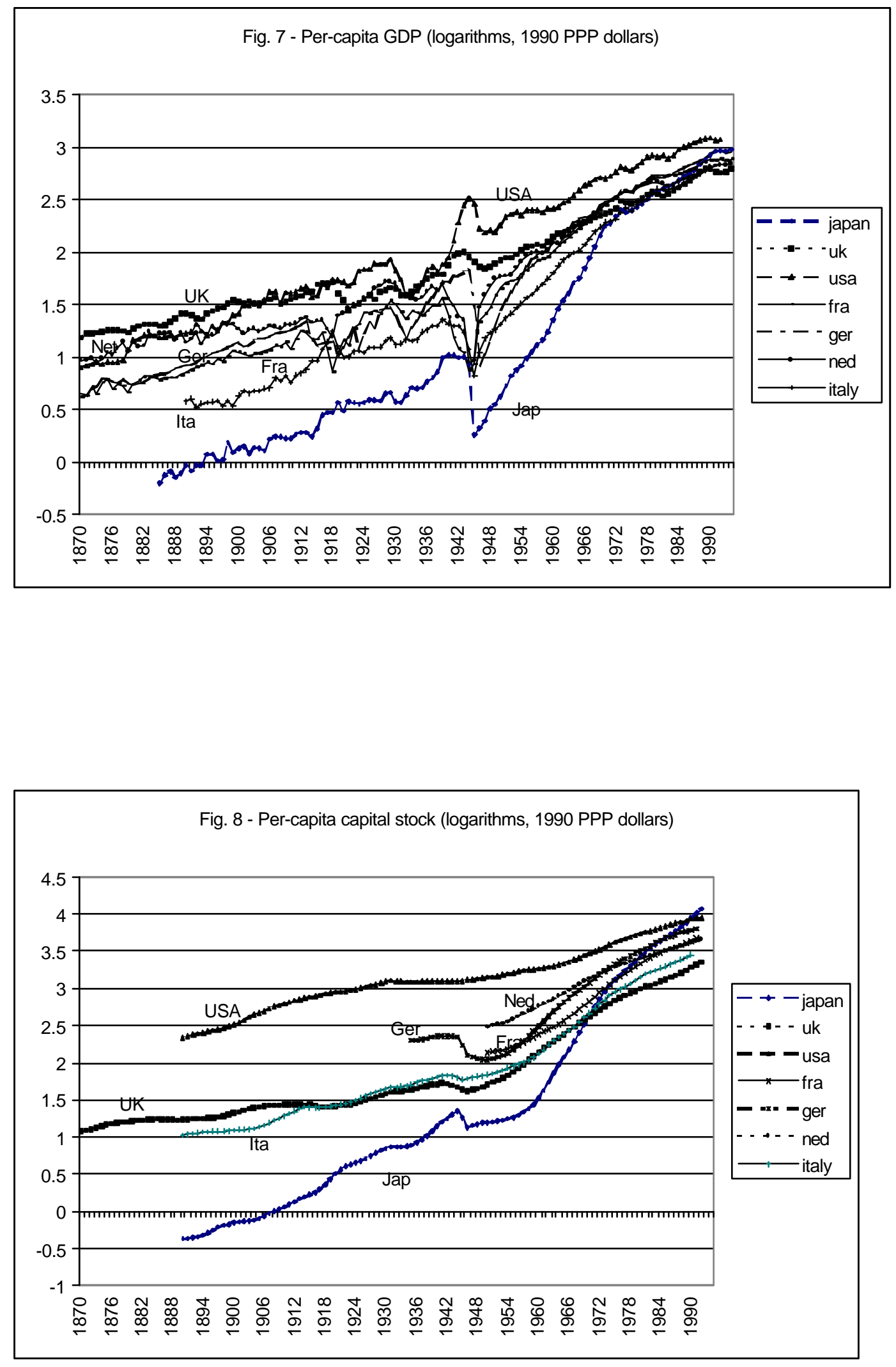